\title{
"Decompression and paraspinous tension band" Versus "minimal access": Lumbar spinal stenosis and degenerative spondylolisthesis
}

\author{
Kaptan H \\ Department of Neurosurgery, Dokuz Eylül University Faculty of Medicine, Turkey
}

\section{Dear Editor,}

Some authors have presented a literature search on MEDLINE/ PUBMED to review current reports describing clinical outcomes or complications associated with the decompression and PTB (paraspinous tension band) of lumbar stenosis and degenerative spondylolisthesis.

In this case, we must emphasize; open laminectomies, unilateral approach bilateral decompression with-without using tubular retractors and microsurgical bilateral approaches for decompression.

The literature supports this common opinion [1-5]. But, without using microsurgical approaches, this surgical strategy would be lacking.

I would like to highlight some points. "Minimal access" with open laminectomies may not lead to case of iatrogenic spinal instability. Thus, additional surgical intervention for instrumentation-PTB is not need. Decrease in operative blood loss, length of hospital stay (1 or 2 days) is generally observed in our patient. We did not use prepostoperative narcotic but only analgesics. Operative time took 1-2 hours. There are not any patients with intraoperative CSF leakage.

Another discussion point is the question about whether the PTB would be necessary or not for lumbar stenosis because PTB is at a great cost. In addition, we can reach the same conclusion in other surgical methods (Minimal access" with open laminectomies or microsurgical decompression)

In my opinion; partial laminectomy is more applicable for the patients who are below 65 years. A more positive improvement was observed; total laminectomy is more suitable for patients above the age of $\mathbf{7 5}$ years. Nerve root decompression surgery is performed and in order to maintain a stable and balanced spine. In addition, our clinical experience shows that microsurgical unilateral approach for bilateral decompression of lumbar is better than open laminectomies. This method seemed advantageous in minimizing the procedure and accompanying morbidity in this elderly population [2-4].

As a conclusion, we always prefer "Minimal access" with open laminectomies or microsurgical decompression.

Best Regards,

The authors have no personal financial or institutional interests in any of the materials or devices mentioned in the article.

\section{References}

1. Müslüman AM, Cansever T, Yılmaz A, Çavuşoğlu H, Yüce İ, et al. (2011) Midterm outcome after a microsurgical unilateral approach for bilateral decompression of lumbar degenerative spondylolisthesis. J Neurosurg Spine 16: 68-76. [Crossref]

2. Kaptan H, Kasımcan O, Çakıroğlu K, İlhan MN, Kılıç C (2007) Lumbar spinal Stenosis in Eldery Patients. Annals of The New York Academy of Sciences 1100: 173-178.

3. Kaptan H, İlhan M, Çakıroğlu K, Kasımcan Ö , Kılıç C (2010) The Analysis of the Factors Affecting Lumbar Spinal Stenosis In Adult Patients. Ir J Med Sci 179: 365-368. [Crossref]

4. Morgalla MH, Noak N, Merkle M, Tatagiba MS (2011) Lumbar spinal stenosis in elderly patients: is a unilateral microsurgical approach sufficient for decompression? $J$ Neurosurg Spine 14: 305-312. [Crossref]

5. Fourney DR, Dettori JR, Norvell DC, Dekutoski MB (2010) Does minimal access tubular assisted spine surgery increase or decrease complications in spinal decompression or fusion? Spine (Phila Pa 1976) 35: S57-65. [Crossref]
Copyright: (C2018 Kaptan H. This is an open-access article distributed under the terms of the Creative Commons Attribution License, which permits unrestricted use, distribution, and reproduction in any medium, provided the original author and source are credited.
*Correspondence to: Hülagü KAPTAN, MD, Assoc. Prof. Department of Neurosurgery, Dokuz Eylül University Medical Faculty, Inciralti 35340 Izmir Türkiye, Tel: +90 50539887 02; E-mail: hulagukaptan@yahoo.com

Received: February 14, 2018; Accepted: February 24, 2018; Published: February 27,2018 